\title{
Development of School Management and Instructional Innovation Plan Based on School Heads Level of Leadership Traits and Work Effectiveness
}

\author{
Dennis B. Roble ${ }^{1}$, Minda S. Rebollido \\ ${ }^{1}$ University of Science and Technology of Southern Philippines, Lapasan Highway, Cagayan de Oro City, Philippines \\ ${ }^{2}$ City National High School, Department of Education, Division of CDO, Nazareth, Cagayan de Oro City, Philippines
}

\begin{abstract}
School leadership plays an indispensable role in the effectiveness of an educational institution, right from the setting to the accomplishment of the school mission, vision and goals. School administrators' leadership attributes play a vital role towards student's achievements and general school effectiveness. This study determines the degree of school administrator's leadership traits (decisiveness, integrity, commitment, initiative, courtesy, human relations and stress tolerance) and work effectiveness (instructional leadership, learning environment, human resource and management, school community partnership and school management and operations) as perceived by the school administrators and teachers. Further, this study find out the predictors of school administrator's leadership traits and work effectiveness as well the degree of relationship between these variables. Data were analyzed using frequency count, percentage, mean, and correlation and regression analysis. Result of the analysis showed that the in terms of school heads' leadership traits and work effectiveness, the school heads look at themselves as highly effective while the teacher-respondents viewed them as only effective. Moreover, the school heads level of stress tolerance showed a strong impact on the school heads level of work effectiveness in the school operations and management while others showed moderate to weak relationship as perceived by the school heads, on the other hand, in terms of the teacher-respondents perspective, in all indicators of school heads work effectiveness and leadership traits, they showed strong association with each other. Both the school heads and teachers admitted that human relations and human resource and management were important components to achieve an efficient instructional and management leadership and thus promoting success in students' learning. The researcher the recommends that the school heads' leadership traits and work effectiveness should be constantly monitored by Department of Education officials to continually attain the goals and objectives of all secondary schools and establish a healthy balance between work and traits for a productive leadership of a school head and gain strong support from the teachers and other stakeholders. Both internal and external stakeholders may work together in providing quality education to students who can become educational leaders in the future.
\end{abstract}

Keywords: leadership traits, work effectiveness, school heads

\section{Introduction}

School leadership plays an indispensable role in effectiveness of an educational institution, right from the setting of goals to accomplishment of goals. In view of Cheng and Townsend (2000) for education change and effectiveness, the role of principal is often crucial to their success. The principal is challenged to create the culture of equality that penetrates to the smallest elements, processes and the systems of an institution. It is common experience that under the same set of rules and regulations, with the same set of teaching staff and students from similar background, an educational institution degenerated or maintains status quo, or rise to prominence with a change of principal. This is also borne out of large number of research studies on management of change in education (Mukhaopadhyay, 2012).

Principals' leadership attributes play a vital role towards student's achievements and general school effectiveness. Studies have shown that, principals attributes is concerned with the overall improvement and effectiveness of the school, and the academic of every student (Goldring and Pasternack, 1994). Meanwhile, professional leadership training is very vital for school principals in order to enable them to develop and improve their leadership attributes to meet up with the necessary demands of secondary schools. Thus, school improvement efforts rely heavily on quality leadership.

Furthermore, principals set the direction of schools that promote positive and productive workplaces for teachers and vibrant learning environments for learners. They need to be educational visionaries, public relation experts and budget analysts. They also act as instructional leaders. They create and direct instructional programs that incorporates current research on instructional methods and who directs teaching efforts in curriculum and classroom instruction, student assessment and program design (Baron, 1983).

According to Philip Hallinger and Ronald Heck (1998), school principals exercise a measurable, though indirect effect on school effectiveness and student achievement. Education as a field of study has finally embraced school leadership as an essential ingredient in reform, worthy of investment in its own right. Principals are faced with escalating challenges based on the various demands from different classes of students, to meet up with these demands and reform, school principals should be well prepared to change their leadership attributes/traits towards school effectiveness (Mitgang 2012).

Volume 6 Issue 1, January 2017 


\section{International Journal of Science and Research (IJSR) \\ ISSN (Online): 2319-7064}

Index Copernicus Value (2015): 78.96 | Impact Factor (2015): 6.391

There are certain characteristics of a principal that some people do not possess. Besides the obvious professional requirements needed to become a principal, there are several traits that good principals must possess to do their job effectively. Some of these qualities that best principals possess are: 1) A principal must exhibit leadership. The principal is the instructional leader of their building. He has to take responsibility both in the successes and failures of their school; 2) a principal must be adept with people. He has to be able to connect with each person that he deals with. He has to find common ground and even their trust; 3) a principal must balance tough love with earned praise. This is especially true with your students and your teachers. There will be times when you have to reprimand people and likely hurt their feelings. At the same time you must offer praise when it is appropriate; and 4) a principal must be fair and consistent. Now more than ever schools need great leaders. School heads' are expected to show their ability to ensure student learning and increase achievement.

This study, therefore, attempts to find out the leadership traits and work performance of public secondary school heads. The result of the analysis would be the baseline data for the development of school management and instructional innovation plan for school heads.

\section{Conceptual Framework}

Leadership is one of those nebulous terms. The traits that make up a good leader can vary depending on the organization, team, and work environment. Leadership can also vary in style. "Every leader has a particular style of leadership that is innate. However, the behaviors, attitudes or methods of delivery that are effective for one staff member may in fact be counterproductive for another," says Michael Burke, account supervisor (MSR Communications, a public relations firm).

Among the many traits of a good leader, Rachel Fisher-Lyne, vice president of media relations, JCPR, considers the following as traits that make up a good leader: 1. Honesty Always do the honest thing. It makes employees feel like they know where they stand with you at all times; 2. Focus Know where you're going and have strong stated mission to lead people on; 3. Passion - Whatever it is, you must have passion for what you're doing; 4. Respect - Not playing favorites with people and treating all people no matter what station in life, what class or what rank in the organizational chart - the same; and 5. Excellent persuasion abilitiesPeople have to believe in you and your credibility.

In this study, the following leadership traits; namely,1) decisiveness, 2) integrity, 3) dedication, 4) initiative, 5) courtesy, 6) human relations, and 7) stress tolerance are adopted from the Performance Appraisal System for School Administrators (PASSA). Likewise, as for the work performance of the school heads, the following are used: 1) instructional leadership, 2) learning environment, 3) human resource management, 5) school community partnership, 6) school management and operations. These work performance variables are based on the duties and responsibilities of a school head in the Results - Based Performance Management System (RPMS) of the Department of Education (DepEd).

On the other hand, a school principal is also an instructional leader. The role of instructional leader by school leaders is now emphasized. This role was influenced largely by research which found that effective schools usually had principals who stressed the importance of instructional leadership (Brookover and Lezotte, 1982.) Recently instructional leadership has placed an increasing importance on academic standards and the need for schools to be accountable.

While most agree that instructional leadership is critical in the realization of effective schools, it is seldom practiced. For example, among the many tasks performed by principals, only one-tenth of time is devoted toward providing instructional leadership (Stronge, 1988). Even today, school leaders continue to seek balance in their manageradministrator and instructional leader. Interestingly, among the reasons cited for less emphasis given to instructional leadership is the lack of in depth training for their role as an instructional leader, lack of time to execute instructional activities, increased paper work, and the community's expectation that the principal's role is that of a manager (Flath, 1989; Fullan, 1991). Avolio (2005) makes a compelling case for leadership development based on the view that "leaders are made not born". Performance and traits of effective leaders are acquired through a learning process and systematic preparation. The ability of the teachers to use what they know in order to produce successful students depends on the influence of the school heads' leadership performance and attributes.

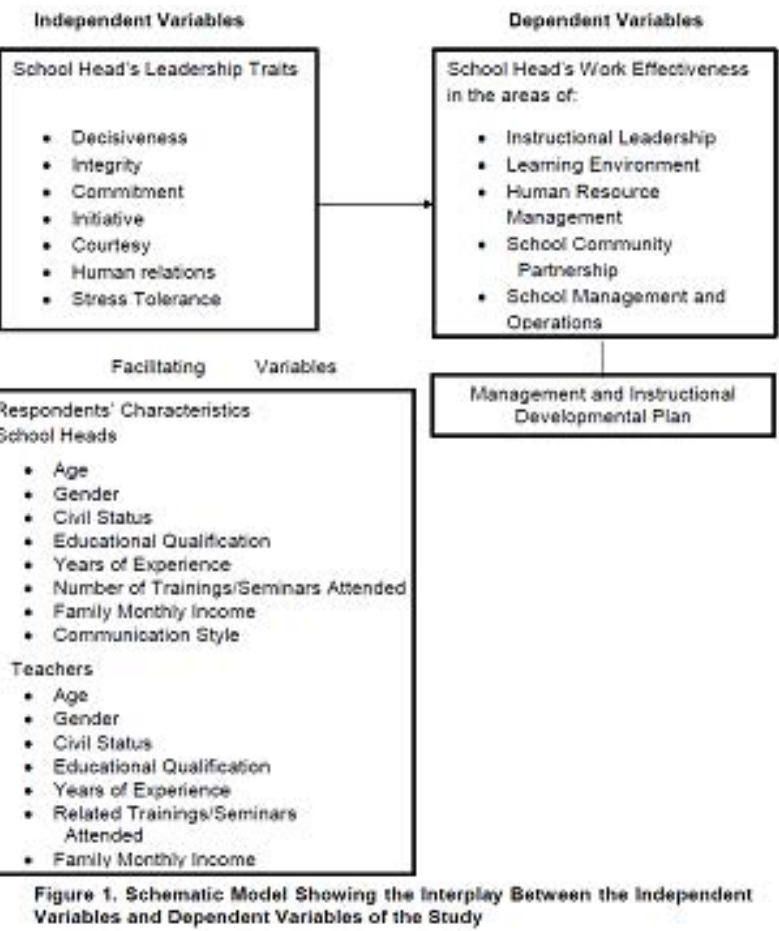

\section{Literature Review}

Leadership is a process through which an individual influence a group of people to attain common goals. Leaders now don't rely upon their legitimate power to persuade 


\section{International Journal of Science and Research (IJSR) \\ ISSN (Online): 2319-7064 \\ Index Copernicus Value (2015): 78.96 | Impact Factor (2015): 6.391}

individuals to do as they are told but they take an interest in an interaction with their subordinates or they raise and widen the interest of their subordinates (Northouse, 2007). People attribute leadership to several qualities, responsibilities, role, and functions. (Giltinane, 2013) There are many definitions of leadership, one of which says that "Leadership engrosses social influence process in which one individual exerts intentional influence over others to structure activities and relationships in a group or organization" (Tatlah et al., 2012) Several studies of the past reveal that the leadership is the single most important agent for a school as an organization to be functioning successfully. A few examples of the tasks of the school principal as a leader are: clarifying the school's vision, mission and goals, sustaining a good relationship with teachers and staff, directing the classroom practices of teachers, arranging the curriculum and instruction, making certain the students opportunity to learn, and performing in accordance with standards (Onorato, 2013). School principal's leadership styles showed significant relationship with school effectiveness (Iqbal \& Tatlah, 2012). School leadership has a stronger effect on the attitude of teachers towards their jobs. The role of school leaders has changed and the success of any school relies on the leadership styles practiced school administrators. According to Webb, Darling \& Alvey (2014) true school leaders engage stakeholders with their consideration and modesty because they involve themselves in what they are actually doing not for individual gains.

According to Kara Uysal, Sirgy and Lee (2013) in a school effective principal give importance to their own behaviors that influence, motivate and encourage the teachers. The teachers expect their principal to guide them and support them in their professional, interpersonal and individual lives. They provide occasions to integrate the formal and informal aspects of the school, e.g. like they make use of all the opportunities to celebrate the success of the school whether be it in meetings or ceremonies (Turan \& Bektas, 2013).

According to Huang (2011), the leaders have the power as well as the capacity to increase and uphold commitment and satisfaction of the employees. For example, all the employees everywhere feel the need to be appreciated, recognized, encouraged, supported and valued by their administrators and colleagues. If the leaders are able to answer this need and make their employees feel wanted, useful, proficient, and important, this will in turn bring teachers to a high level of organizational commitment (Karsli \& Skender, 2009).

Leadership is a process where the leader by implementing appropriate leadership styles influences the feelings and behaviors of the employees. The manners of the leader provoke the atmosphere of the workplace that affects feeling of the employees' towards their job (Voon, Lu, Ngui, \& Ayob, 2011). Leadership style is a rich construct related to many employee and organizational variables for example, organizational commitment, employee performance, organizational culture, job satisfaction and employee motivation (Kara et al., 2013).

Effective school managers are expected to be academically goal oriented and supervise instructional and co-curricular practices accordingly. They motivate and support the teachers, encourage the community and other school stakeholders to be involved in the educational program, and encourage participatory decision making. They are also faced with the complex task of creating a school wide vision, being an instructional leader- planning for effective professional development, guiding teachers, handling discipline, attending important events and needs, and all the other minute details that come with supervising and managing a school (Richard 2000).

The greatest accountability of school heads is to improve learning outcomes in their schools. Rule VI, Section 6.2 of RA 9155 states that school heads have to be accountable for higher learning outcomes by setting the mission, vision, goals and objectives of the school; creating an environment that is caring and welcoming for all students where teaching and learning will thrive; implementing and monitoring of curriculum at the same time offering educational programs and services that will benefit all students. The ability of a school head to overcome challenges depends on the skills developed as an individual. As claimed by Davis (1985) cited by Yee (1984), the school head brings into his job certain capacities of the mind, emotion and spirit. Consequently, he brings along with him his personal traits. The capacities mentioned earlier are coined in Erickson's psychosocial term (Lucas, et. al., 2004) psychological relating to mind, brain and personality. The personality of an individual as advanced by Erickson's theory is a gradual build-up of experiences of an individual as influenced by his environment.

Licuanan (1994) found that the outstanding public elementary school in the country also have effective principals. There is a direct and positive significant correlation between effective principals and effective schools.

The study of Daham (1983) on the competencies of Elementary School Principals in the Division of Sulu revealed that school principals were considered moderately competent in five dimensions of tasks area, namely; improving instructional program, improving personnel services, improving school-community relationship, improving financial and physical resources.

In the study of Fornilos (1983) on the personality traits and supervisory effectiveness of college deans and department heads of private colleges and universities in Region $\mathrm{X}$, findings revealed that a highly significant positive association exits between the overall personality traits of college deans and department heads and their supervisory effectiveness. A high overall personality rating is generally associated with good or effective supervision, and low overall personality rating is associated with poor or ineffective supervision. In like manner, the study of Carcillar (1982) pointed out that effective supervision results in improved academic performance of pupils and professional and creative teachers. As such a significant relationship between the administrator's supervisory practices and academic performance of their pupils existed. Valdez (1978) study, on the other hand, emphasized that the consideration behavior of the principals was not influenced by their personal characteristics,

\section{Volume 6 Issue 1, January 2017}




\section{International Journal of Science and Research (IJSR) \\ ISSN (Online): 2319-7064 \\ Index Copernicus Value (2015): 78.96 | Impact Factor (2015): 6.391}

emotional qualification, total length of experience as an administrator. But she added that school organization climate was significantly related to certain personality and social variables.

The study of Noah (cited in Cartel, 1992) on the Correlates of Job Performance of Elementary School Administrators, indicated the following findings: 1) the respondent's age, years of experience, personality factors and leadership skills were highly associated with their job performance; and 2) the respondent's sex, educational attainment and level of income were slightly correlated with their job performance.

The study of Hemphills (cited in Timbang, 1995) showed that administrators with more experience, were adept in human relationship, directed the work of others, and analyzed the situation and that their performance seemed to result in somewhat better instructional program.

The contemporary educational environment proves to be the greatest challenge for majority of school principals in leading their schools to meet up with the required proficiency levels of student achievements as well as general effectiveness of the school (Mathibe, 2007). The interest toward strong educational leadership in 21 st Century is based on the certainty that, principals' leadership attributes in schools makes a substantial difference to student achievement and the effectiveness of secondary schools.

Education as field of study has finally embrace school leadership as an essential ingredient in reform, working of investment in its own right. Principals are faced with escalating challenges based on various elements from different classes of students to even the community to meet up with these demands and reform, school principals should be well prepared to change their leadership attributes towards school effectiveness, not just manage buildings and budgets (Mitgang, 2012).

Principal is in better position to safeguard the outstanding teaching and learning in every classroom within the secondary schools. In fact, principals' leadership traits is a factor succeeding the quality teaching among schools towards influencing teaching and learning condition. Iqbal and Tatlah (2012) made a study on the empirical evidence of the school heads leadership styles and school effectiveness and result showed that the significant factor responsible for affecting the achievement of the school is the degree to which head-teachers are participative and adopt the selling leadership style. Results further showed that there was a considerable relationship of leadership styles with school effectiveness and there is a significant difference between leadership styles of head-teachers / deputy head-teachers on the bases of gender both for public and private sectors.

Saleem (2015) conducted a study on the impact of leadership styles on job satisfaction and mediating role of perceived organizational politics. Findings revealed that transformational leadership has a positive impact on job satisfaction and transactional leadership has a negative impact on job satisfaction. Findings also suggest that, perceived organizational politics partially mediate the relationship between both leadership styles and job satisfaction.

Cohen (2015) also made a study on school principal leadership styles and teacher and principal attitudes, concerns and competencies regarding inclusion. Significant relationships were found between years of teaching in special education and leadership styles. Favorable attitudes towards inclusion as well as several concerns were also noted. Both principals and their teachers felt that they had major inclusion competencies. Several, however, received a low rating. Other findings have shown a strong positive correlation between the principals' judgment regarding their leadership styles and the perceptions by teachers in their schools about those styles. Effective principals maintain daily interactions with their teachers, share their visions and support change. They assign tasks and delegate responsibilities while considering their needs and reward them for their performance. Moreover, years of experience were related to leadership style. More experienced principals displayed more effective and active leadership styles (i.e., Transformational \& Transactional styles), while limited experience was translated into the passive and ineffective LF style. Principals and teachers expressed similar positive views in support of inclusion. Support for the movement and philosophy of inclusion is also reported by other researchers. Findings have also shown that seniority (years of teaching experience) was negatively related to positive attitudes toward inclusion. Several other researchers also reported that teachers with fewer years of experience hold more supportive attitudes compared to more senior teachers (Dror \& Weisel, 2003). One explanation is that younger teachers received more recent and updated preparation in special education. It was noted that teachers with a special education certificate held more positive views and more concerns and, as expected, reported more competencies compared to those with an elementary certificate (Cohen \& Leyser, 2004).

Sirisookslipa, Ariratanaa, \& Ngang (2015) made a study on the impact of leadership styles of school administrators on affecting teacher effectiveness. Findings showed that there are two types of leadership styles of school administrators, namely supportive leadership and participative leadership styles which have significantly affecting teacher effectiveness. In addition, both leadership styles have been jointly predicted teacher effectiveness at 56.80 percent at the significance level as 0.01 . In conclusion, in order to increase teachers' working effectiveness, administrators should promote, practice, and improve these two leadership styles, namely supportive leadership and participative leadership styles regularly. The findings above supported by the studies of Waro's (2006) study. Waro found that leadership factor that affecting school effectiveness was the situational factor, administrators' behavior and background. It was also supported by Contingency leadership theories that effective leadership was based on many factors, such as leaders' characteristics, leadership behavior, and related situation as important factors for administrators to implement their duties smoothly. It was congruent with Sureeporn's (2006) study. Sureeporn found that the behaviors of supportive leaders, participatory leaders, and coercive leaders were the predictors of teacher motivation in their work practices.

\section{Volume 6 Issue 1, January 2017}




\section{International Journal of Science and Research (IJSR) \\ ISSN (Online): 2319-7064}

Index Copernicus Value (2015): 78.96 Impact Factor (2015): 6.391

Teachers attempted to develop themselves in improving their knowledge and teaching methods or techniques by attending seminar until they did not have time to take care of their students with full efficiency can be one of reason to explain student quality was low. This was supported by Koonnaree's (2009) study. Koonnaree revealed that direct and indirect influence of high organizational commitment of teachers' transformational leadership would cause students' low quality.

Some of the traits that seemed to characterize successful leaders, according to Stogdill (1972), are the following: a strong drive for responsibility and the devotion to complete the tasks; a persistent spirit in the pursuit of established goals; venture sameness and originality in problem solving; drive to exercise initiative in social settings; self-confidence and strong personal identity; willingness to accept the consequences of one's actions and decisions; readiness to absorb stress and a willingness to tolerate frustration and delay; and ability to influence the behavior of others, a capacity to structure interpersonal relations in a way that facilitates and accomplished the goals at hand. Obviously, to be an effective leader, one must possess certain character traits. A school administrator must possess certain relationship traits. However, according to Martires and Fule (2000), there has been no consistent pattern of relationship between traits and leadership ability. Kontz, O'Donhell and Weinrich (1980) observed that not all leaders possess all traits; many non-leaders may possess most of it.

A research conducted by the University of Minnesota and Toronto accentuated that, based on the data analyzed from 180 schools in nine states of the United States of America, there is no particular school improving it student achievement in the absence of strong educational leadership (Mitgang, 2012).

Stanford University's Linda Darling-Hammond, a leading education scholar, emphasizes the profound impact good leaders have on teaching quality. It is the work of the school principals that enables teachers to be effective. The ability of the teachers to use what they know in order to produce successful students depends on the influence of the principals' leadership traits.

The National Association of Secondary School Principals (NASSP), as cited in the research paper of Bagobiri, Asimiran and Basri (G. J. C. M. P., Vol. 3 (3): 40-44, emphasized the ability of the principal as school leader to accomplish the following:

- Design effective learning environments for a wide range of students.

- Develop teams, delegate responsibilities and include team members from the community.

- Comment orally and in writing with acute sensitivity to diversity of public.

- Motivate students and staff to reach high expectation.

- Use technology to assist in instructing students and to manage the school.

- Evaluate programs and be accountable for student learning.
- Value and integrate culturally diverse students and staff into the life the school.

- Work within the political forces with shape schooling (Cunningham, 2000).

Moreover, various researches have also tried to interpret school leadership in different manner. Peretomode (1991) stated the importance of Leadership in school for accomplishment of school programs, objectives and attainment of educational goals. Cheng (1994) proposed that leadership in educational institutions compose of five major dimensions, namely: structural leadership, human leadership, political leadership, cultural leadership and educational leadership. These five dimensions describe the role and functions of school leader.

Brown, as cited by Sirad (1999), conducted a study on the perceptions of selected secondary school principals regarding the actual and desired instructional leadership practices of secondary school principals. It was found that 1) perceptional differences existed between principals and teachers in all two major categories in the management of instruction and curriculum and 2) perception differences existed between principals and teachers in actual allocation of time the principals have spent in instructional leadership. Findings revealed that many principals were not actively involved in the improvement of instruction in a systematic manner and were not knowledgeable about their role in the teachinglearning process. Many principals lacked effective supervisory skills and attitude designed to improve the instructional skills of the teachers.

Researches done in the recent years on leadership and management disclose a higher measure of impact of leadership style on greater level of organizational commitment (Omidifar, 2013). Without the strong support of the committed staff no leader can make the organization effective and successful (Nordin, 2011). Leaders possess the knowledge, power, skill, responsibility and position to shape the behaviors of the staff through their different leadership styles (Keskes, 2013). Leadership success can be measured by the quality of employees' commitment (Nordin, 2011). Givens (2008) added that leadership is an essential component to commitment.

Shams-Ur-Rehman (2012) explored the predictive relationship between transformational and transactional leadership to organizational commitment. The results revealed a significant predictive relationship but transformational leadership correlation slightly higher than transactional leadership $(.327, .310)$. Selamat, Nordin (2013) study investigated correlation between perceived transformational leadership behavior and organizational commitment of 186 secondary level teachers. Results showed that a strong relationship existed between transformational leadership behavior and organizational commitment.

A teacher who is committed will be proud of her school. She will accept any responsibility for the success of her school and her commitment has an effect on the students and the organization. For instance, she is willing go extra miles to 


\section{International Journal of Science and Research (IJSR) \\ ISSN (Online): 2319-7064 \\ Index Copernicus Value (2015): 78.96 | Impact Factor (2015): 6.391}

reach out to her students whether within or outside the classroom, and give additional coaching to those who do not succeed (Huang, 2011). Teachers with strong commitment show interest and participate wholeheartedly in all the activities and undertakings of the school (Gupta \& Gehlawat, 2013).

These review of related literature and research studies are in some aspect related to the present study. They have provided the researcher a chance to study further the leadership traits and performance of secondary school heads for school effectiveness in the Division of Cagayan de Oro City and as basis for a proposed management and instructional developmental plan.

\section{Methodology}

The study utilized the descriptive survey research design. This design is most appropriate for the purpose of inquiry which will critically determine the relationship of the leadership traits of the school heads and their work performance. The study will use the correlational technique to ascertain the extent or magnitude of the relationship between the school heads' leadership traits and their work performance. Survey questionnaires was used to gather the needed data on the school heads' and teachers' profile, leadership traits and work performance.

Focus Group Discussion and In-depth Interview was used to elicit further information, follow up on some issues and provide deeper opinions, perspectives, points of view and motives of the respondents for some thoughts or opinions based on their experiences and observation of the organization. For purposes of triangulation, an in-depth interview was conducted to pursue certain interesting or provocative lines of thought and to confirm the answers of the respondents.

This study was conducted in the Division of Cagayan de Oro City, School Year 2016-2017.Specifically, the Division is composed of two (2) legislative districts; namely, Legislative District 1 and Legislative District 2. The Division of Cagayan de Oro City used to be a part of the Division of Misamis Oriental, Philippines. In August 1953, Cagayan de Oro City was created as a separate Division. A year after, the Division was returned to the Division of Misamis Oriental, there being no Schools Division Superintendent. But on May 1, 1963, it stood again as a separate Division.

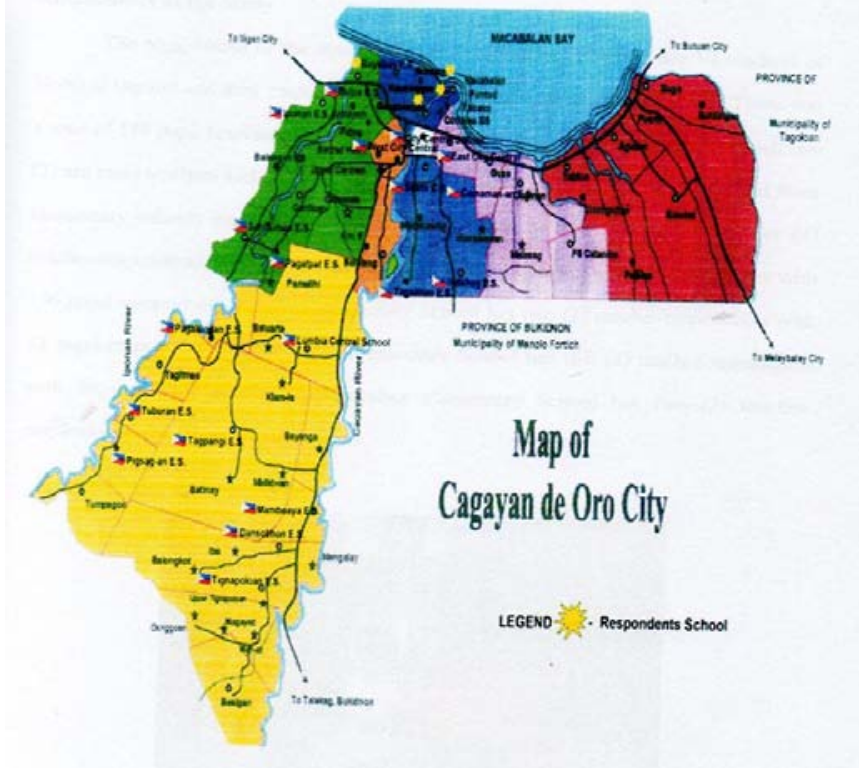

Figure 2: Map of the Division of Cagayan de Oro City

The data collected, tabulated and analyzed using different statistical techniques. Frequency count and percentages was used to present the socio-demographic profile of the school heads and teachers according to their age, gender, civil status/marital status, highest degree obtained, years of experience as school head, trainings/seminars attended, and family monthly income. Mean and standard deviation was used to determine the level of leadership traits and work performance of the school heads. Pearson correlational analysis was used to determine the extent of relationship between leadership traits and work performance of school heads and one-way analysis of variance (ANOVA) and F-test was used to determine the significant difference between the school heads leadership traits and work performance when grouped according to the profile variables.

\section{Results and Findings}

Table 1. School Administrators' Level of Leadership Traits as Rated by the School Heads and Teachers

\begin{tabular}{|c|c|c|c|c|}
\hline \multirow[t]{2}{*}{$\begin{array}{l}\text { Leadership Traits } \\
\text { Indicators }\end{array}$} & \multicolumn{2}{|c|}{$\begin{array}{c}\text { School Head's Rating } \\
\qquad=20\end{array}$} & \multicolumn{2}{|c|}{$\begin{array}{c}\text { Teachers' Rating } \\
n=662\end{array}$} \\
\hline & Mean & Description & Mean & Description \\
\hline Decisiveness & 3.60 & Highly Effective & 3.18 & Effective \\
\hline Integrity & 3.69 & Highly Effective & 3.26 & Effective \\
\hline Commitment & 3.82 & Highly Effective & 3.25 & Effective \\
\hline Initiative & 3.72 & Highly Effective & 3.22 & Effective \\
\hline Courtesy & 3.86 & Highly Effective & 3.28 & Effective \\
\hline Human Relations & 3.71 & Highly Effective & 3.26 & Effective \\
\hline Stress Tolerance & 3.52 & Highly Effective & 3.18 & Effective \\
\hline Overall & 3.70 & Highly Effective & 3.23 & Effective \\
\hline $\begin{array}{l}\text { Mean Intervals } \\
3.50-4.00 \\
2.50-3.49 \\
1.50-2.49 \\
1.00-1.49\end{array}$ & $\begin{array}{l}\text { ption } \\
\text { Effective } \\
\text { ve } \\
\text { tive } \\
\text { Ineffective }\end{array}$ & & & \\
\hline
\end{tabular}

The school administrator's level of leadership traits in terms of decisiveness, integrity, commitment, initiative, courtesy, human relations and stress tolerance was highly effective as rated by themselves as indicated by the mean of 3.70 while the teacher respondents rated them as effective only as indicated by the mean level of 3.23. This result implies that the teachers showed a different perception with the school

\section{Volume 6 Issue 1, January 2017}




\section{International Journal of Science and Research (IJSR) \\ ISSN (Online): 2319-7064}

Index Copernicus Value (2015): 78.96 | Impact Factor (2015): 6.391

administrators. Also evident in the table that the school heads and teachers rated level of courtesy of school heads highest while both scored lowest the school administrator's level of stress tolerance. This implies that to achieve the same level of perception, the school administrators may consider finding ways in which the two parties would have the same perception. Moreover, the school administrators should engage themselves to activities or mechanisms which may help facilitate in coping their stress.

Table 2. School Administrators' Level of Work Effectiveness as Rated by the School Heads and Teachers

\begin{tabular}{|c|c|c|c|c|}
\hline \multirow[t]{2}{*}{ Work Effectiveness Indicators } & \multicolumn{2}{|c|}{$\begin{array}{c}\text { School Head's Rating } \\
n=20\end{array}$} & \multicolumn{2}{|c|}{$\begin{array}{c}\text { Teachers' Rating } \\
n=662\end{array}$} \\
\hline & Mean & Description & Mean & Description \\
\hline Instructional Leadership & 3.59 & Highly Effective & 3.29 & Effective \\
\hline Learning Environment & 3.59 & Highly Effective & 3.28 & Effective \\
\hline Human Resource and Management & 3.62 & Highly Effective & 3.24 & Effective \\
\hline School Community Partnership & 3.62 & Highly Effective & 3.36 & Effective \\
\hline School Management and Operations & 3.55 & Highly Effective & 3.30 & Effective \\
\hline Overall & 3.59 & Highly Effective & 3.29 & Effective \\
\hline $\begin{array}{l}\text { Mean Intervals } \\
3.50-4.00 \\
2.50-3.49 \\
1.50-2.49 \\
1.00-1.49\end{array}$ & & & & \\
\hline
\end{tabular}

There was still a disparity between the school head's and teachers rating on their level of work effectiveness. The school head's rated their level of work effectiveness as highly effective in all indicators as well as the overall rating while the teachers rated them only as effective as indicated by the mean level of 3.29. Again, the school need to improve their work effectiveness so the teachers may rate them as highly effective. The teachers may not be well satisfied by the performance of the school administrators most especially on the aspect of human resource and management as well as on the learning environment.

Table 3. Relationship of School Administrators (SA) Leadership Traits and Work Effectiveness from the School Administrators' and Teachers' Perspective

\begin{tabular}{|c|c|c|c|c|c|c|c|}
\hline \multirow{2}{*}{$\begin{array}{l}\text { Indicators of School } \\
\text { Heads } \\
\text { Work Effectiveness }\end{array}$} & \multicolumn{7}{|c|}{ Indicators of School Heads Leadership Traits } \\
\hline & Decisiveness & Integrity & commitment & Initiative & Courtesy & $\begin{array}{c}\text { Human } \\
\text { Relations }\end{array}$ & $\begin{array}{c}\text { Stress } \\
\text { Tolerance }\end{array}$ \\
\hline $\begin{array}{|ll|}\begin{array}{l}\text { Instructional } \\
\text { Leadership }\end{array} & \text { SA } \\
\end{array}$ & 0.329 & 0.172 & 0.338 & 0.518 & 0.156 & 0.255 & 0.686 \\
\hline Teachers & 0.667 & 0.669 & 0.705 & 0.725 & 0.646 & 0.705 & 0.677 \\
\hline $\begin{array}{l}\text { Learning } \\
\text { Environment }\end{array}$ & 0.501 & 0.326 & 0.222 & 0.373 & 0.160 & 0.231 & 0.691 \\
\hline Teachers & 0.701 & 0.690 & 0.718 & 0.742 & 0.637 & 0.728 & 0.677 \\
\hline $\begin{array}{ll}\begin{array}{l}\text { Human Resource } \\
\text { and Management }\end{array} & \text { SA }\end{array}$ & 0.583 & 0.577 & 0.254 & 0.318 & 0.412 & 0.194 & 0.560 \\
\hline Teachers & 0.681 & 0.700 & 0.725 & 0.731 & 0.658 & 0.726 & 0.662 \\
\hline \begin{tabular}{|l|} 
School Community \\
Partnership
\end{tabular} & 0.436 & 0.463 & 0.360 & 0.635 & 0.524 & 0.299 & 0.799 \\
\hline Teachers & 0.615 & 0.647 & 0.669 & 0.694 & 0.608 & 0.705 & 0.615 \\
\hline $\begin{array}{l}\begin{array}{l}\text { School Management } \\
\text { and Operations }\end{array} \\
\text { SA }\end{array}$ & 0.482 & 0.402 & 0.359 & 0.608 & 0.267 & 0.350 & 0.822 \\
\hline Teachers & 0.673 & 0.687 & 0.688 & 0.735 & 0.610 & 0.722 & 0.650 \\
\hline $\begin{array}{l}\text { Pearson Correlation Coeff } \\
0 \\
0.10-0.49 \\
0.50-0.69 \\
0.70-0.99 \\
1.00\end{array}$ & icient (r) Valu & & $\begin{array}{l}\text { Descripti } \\
\text { No Linear } \\
\text { Weak Pos } \\
\text { Moderate } \\
\text { Strong Po } \\
\text { Perfect Lir }\end{array}$ & $\begin{array}{l}\text { Relations } \\
\text { tive Relat } \\
\text { y Positiv } \\
\text { sitive Re } \\
\text { ear Relat }\end{array}$ & $\begin{array}{l}\text { hip } \\
\text { ionship } \\
\text { e Relation } \\
\text { lationship } \\
\text { onship }\end{array}$ & & \\
\hline
\end{tabular}

In terms of the relationship between school heads leadership traits and work effectiveness, on the school heads' perception, result showed that school heads work effectiveness on human resource management was moderately correlated to their traits such as decisiveness and integrity, while their effectiveness in the school community partnership was also moderately related to their level initiative and courtesy traits and lastly the school heads' level of effectiveness in the school management and operations was strongly correlated to their stress tolerance.

In the teacher-respondents perception, result showed that in terms of instructional leadership, the school heads level of decisiveness, integrity, commitment, initiative, courtesy, human relations and stress tolerance showed strong association. Next, in terms of the work effectiveness of the school head in the learning environment, in all indicators of leadership traits except for courtesy, they showed strong association. On work effectiveness in terms of school community partnership, it showed commitment, initiative and human relations showed strongly positive relationship while the rest of the leadership indicators showed moderately positive correlation and with respect to the school heads effectiveness in school management and operations aspect of work effectiveness, result showed strongly correlation to the school heads leadership traits with the exception of courtesy which only showed moderately positive association.

\section{Conclusions and Recommendations}

The following conclusions were drawn from this study:

a) Majority of the school-head respondents were married male, with age ranging from 46-50 years old, already have doctoral units, with combined monthly income of P35,000 and above and have served as a school head for less than five years. Also, most of these school heads were able to attend many division, regional and national level seminars and trainings while only a few were able to attend seminars in the international level and used memoranda and face-to-face conversation as a means of communication to its stakeholders.

b) Majority of the teacher-respondents were married female with age ranging from 30-35 years old, earned units from their masteral studies, and worked as a classroom teacher in less than five years and had income below P20, 000 and below. Only a few were able to attend national and international level seminars and trainings but many were able to attend division level trainings and seminars relevant to their instruction.

c) The school heads had a high regard of themselves as in all indicators of school heads' leadership traits and work effectiveness, the school heads look at themselves as highly effective while the teacher-respondents viewed them as only effective.

d) School heads stress tolerance showed a strong impact on the school heads level of work effectiveness in the school operations and management while others showed moderate to weak relationship as perceived by the school heads and for the teacher-respondents perspective, in all indicators of 


\section{International Journal of Science and Research (IJSR) \\ ISSN (Online): 2319-7064}

Index Copernicus Value (2015): 78.96 | Impact Factor (2015): 6.391

school heads work effectiveness and leadership traits, they showed strong association with each other.

e) The school heads had the same perception on their level of leadership traits and work effectiveness while the teacherrespondents had the same perception in terms of age, years of experience as classroom teacher and the number of seminars and trainings attended.

f) The school heads and teachers both agree that human relations and human resource and management were important components to achieve an efficient instructional and management leadership and thus promoting success in students' learning.

g) The teachers wanted to have technology aided instruction be available I their classrooms and also they lamented that they needed training on current strategies on teaching and seminars on both content and pedagogy in their field of specialization.

The following recommendations are hereby forwarded:

a) The school heads' leadership traits and work effectiveness should be monitored regularly by the Division Office to continually attain the goals and objectives of all secondary school and establish a healthy balance between work and traits for a productive leadership of a school head and gain strong support from the teachers and other stakeholders

b)Internal and external stakeholders should work together in providing quality education to students who can become educational leaders in the future.

c) The school heads may consider the researcher's proposed management and instructional development plan to improve the quality of instruction and school's performance.

d)An assessment of the effectiveness of the proposed management and instructional development plan may be conducted by future researchers.

e) Further study may be conducted considering other educational leadership traits and the application of leadership theories not within the scope of this study.

\section{References}

[1] Antecol, H., Eren, O., \& Ozbeklik, S. (2012). The effect of teacher gender on student achievement in primary school: evidence from a randomized experiment.

[2] Cohen, E. (2015). Principal Leadership Styles and Teacher and Principal Attitudes, Concerns and Competencies regarding Inclusion. Procedia-Social and Behavioral Sciences, 186, 758-764.

[3] Giltinane, C L. (2013). Leadership styles and theories. Nursing Standards, 27(41), 35-39.

[4] Givens, R. J. (2008). Trans formational leadership: The impact on organizational and personal outcomes. Emerging Leadership Journeys, 1(1 ), 4-24.

[5] Gupta,. \& GehlawatM (2013). A study of the correlates of organizational commitment among secondary school teachers. Issues and Ideas in Education, /, 59-71.

[6] Huang, T. (2011). The relationship between headmasters' leadership behavior and teacher's commitment in primary schools in the district of Sarawak. Procedía- Social and Behavioural Sciences, 29, 1725-1732.

[7] Hussein, H. B. (2007). Saudi secondary school teacher's attitudes' towards using interactive whiteboard in classrooms. TOJET: The Turkish Online Journal of Educational Technology, 11(3)

[8] Kara, D., Uysal, M., Sirgy, M.J., \& Lee, G. (2013). The effects of leadership style on employee well-being in hospitality. International Journal of Hospitality Management 34, 9-18.

[9] Karsli, M.D., \& Skender, H. (2009). To examine the effect of the motivation provided by the administration on the job satisfaction of teachers and their institutional commitment. Procedía- Social and Behavioral Sciences, 1,2252-2257.

[10] Keskes, I. (2013). Relationship between leadership styles and dimensions of employee organizational commitment: A critical review and discussion of future directions. OmniaScience.IO(1).

[11] Koonnaree, T. (2009). School climate affecting job satisfaction of teachers in primary education. Unpublished Master thesis. Khon Kaen, University, Khon Kaen.

[12] Nordin, N. (2011). The influence of emotional intelligence, leadership behaviour and organizational commitment on organizational readiness for change in higher learning institutions. Procedía-Social and Behavioural Sciences. 29,129-138.

[13] Northouse, P. G. (2007). Leadership: Theory and practice (4th ed.). Thousand Oaks, CA: Sage.

[14] Omidifar, R. (2013). Leadership style, organizational commitment and job satisfaction: A case study on high school principals in Tehran, Iran. American Journals of Humanities and Social Sciences, 1(4), 263-267.

[15] Onorato, M., \& Sunny (2013).Transformational leadership style in the educational sector: An empirical study of corporate managers and educational leaders. Academy of Educational Leadership Journal,! 7,33-48.

[16] Saleem, H. (2015). The impact of leadership styles on job satisfaction and mediating role of perceived organizational politics. Procedia-Social and Behavioral Sciences, 172, 563-569.

[17] Selamat,N., Nordin, N., \& Adnan A.A., (2013) Rekindle teachers organizational commitment: The effect of transformational leadership behaviour. Procedía- Social and Behavioural Sciences, 90, 566574.

[18] Shams Ur Rehman (2012). Perceived leadership styles and organizational commitment. Interdisciplinary Journal of Contemporary Research inBusiness,4( 1), 616-626.

[19] Sirisookslip, S., Ariratana, W., \& Ngang, T. K. (2015). The Impact of Leadership Styles of School Administrators on Affecting Teacher Effectiveness. Procedia-Social and Behavioral Sciences, 186, 10311037.

[20] Sureepon, S. (2006). The school administrators' leadership behavior and work motivation of private vocational school teachers. Unpublished Master thesis. Burapa University, Bangkok. 
[21] Tatlah, I. A., \& Iqbal, M. Z. (2012). Leadership styles and school effectiveness: empirical evidence from secondary level. Procedia-Social and Behavioral Sciences, 69, 790-797.

[22] Turan, S., \& Bektas, F (2013). The relationship between school culture and leadership practices. Eurasian Journal of Educational Research, 52,155-168.

[23] Voon, M.L., Lu, M.C., Ngui K.S., \& Ayob N.B. (2011). The influence of leadership styles on employees' job satisfaction in public sector organization in Malaysia. International Journal of Business, Management and Social Sciences, 2(1), 24-32.

[24] Waro, P. (2006). The structural equation modeling of administrator's leadership effectiveness in influencing on school effectiveness. Unpublished Ph.D thesis. Khon Kaen University, Khon Kaen.

[25] Webb, L., Darling, J., \& Alvey, N. (2014). Multicultural Leadership Development in the 21 st Century.

\section{Author Profile}

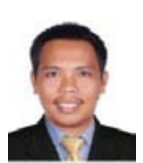

Dennis B. Roble graduated BS in Mathematics at Xavier University, Ateneo de Cagayan, Master of Science in Teaching Mathematics at Mindanao University of Science and Technology and currently on his dissertation writing for the degree $\mathrm{PhD}$ in Mathematics Education at University of Science and Technology of Southern Philippines (USTP). He has served as a Secondary School Teacher in the Department of Education, Division of Cagayan de Oro City and now he is a fulltime faculty member of Math Education Department USTP.

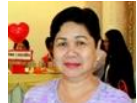

Minda S. Rebollido finished her $\mathrm{PhD}$ in Educational Administration at Cagayan de Oro College (COC) and currently a Secondary School Principal at City National High School of the Department of Education, Division of Cagayan de Oro City, Philippines. She has been a school administrator for several years already and also served as a school administrator for many different schools in both urban and rural areas. Before she became a Principal, she was once an English Teacher in Bulua National High School of the same city. 